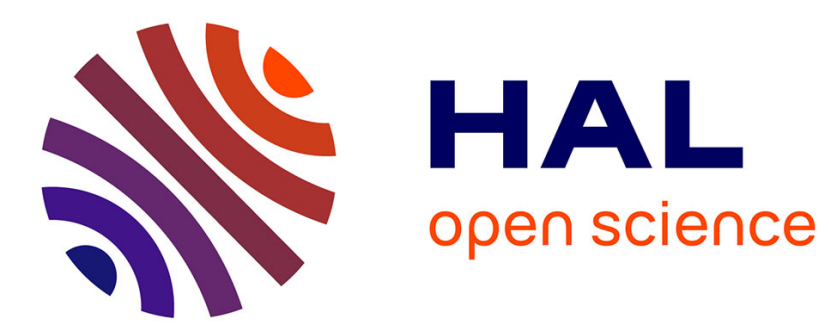

\title{
Conversation and Civility
}

Delphine Denis

\section{To cite this version:}

Delphine Denis. Conversation and Civility. The Oxford Handbook of the Baroque, J. Lyons (éd.), 2019. hal-03244545

\section{HAL Id: hal-03244545 \\ https://hal.sorbonne-universite.fr/hal-03244545}

Submitted on 1 Jun 2021

HAL is a multi-disciplinary open access archive for the deposit and dissemination of scientific research documents, whether they are published or not. The documents may come from teaching and research institutions in France or abroad, or from public or private research centers.
L'archive ouverte pluridisciplinaire HAL, est destinée au dépôt et à la diffusion de documents scientifiques de niveau recherche, publiés ou non, émanant des établissements d'enseignement et de recherche français ou étrangers, des laboratoires publics ou privés. 
[John D Lyons, ed., The Oxford Handbook of the Baroque, New York, Oxford University

Press, 2019, p. 471-486]

\section{Conversation and Civility}

by Delphine Denis

Translated by Raphaëlle J. Burns

In the first dictionary of the Académie française (1694), the entry for the term converser reads as follows: "to be with someone in an ordinary fashion, and to speak casually with them." Indeed, the interactions that take place in such casual company are first and foremost exchanges of opinions and remarks, conducted within the framework of "civil conversation." These types of exchange were modeled on the three great Italian Renaissance treatises on the subject, namely the Book of the Courtier by Baldassare Castiglione (1528), the Galateo by Giovanni della Casa (1558), and the Civil Conversation by Stefano Guazzo (1574), ${ }^{1}$ all of which were rapidly translated into French. France took up this project almost a century later; foreign courts promptly followed suit, perceiving in this culture of civility the nature, indeed the very identity, of the "génie français." This gradual refinement of conduct, or rather its theorization, extended from the 1530s into the middle of the eighteenth century and was at very least a European phenomenon - if one considers the court of Catherine II of Russia. Art historians have named precisely this period, and geographic expanse, the "baroque." France, however, holds a special place within this longue durée, since it was the locus of a determining episode in the elaboration of worldly politeness (politesse mondaine). Indeed, the founding figure of the honnête homme emerged over the course of three decades, from 1630 to 1660.

During these formative years, the mastery of savoir-vivre, taught by innumerable treatises, implied a complete awareness of the role one was to play in society. It is a "rare talent," observes the Chevalier de Méré, at the end of the seventeenth century, and "it takes a great deal of wit and precision to achieve perfection." He continues, "I am convinced that on many occasions it wouldn't be without its uses to regard what one does as a play, and to imagine that one acts a part in the theater." It would be tempting to read this analogy as an avatar of the theatrum mundi metaphor, but such an analysis has its limits: Méré, like his contemporaries, is not denouncing vain illusions in the face of divine transcendence. To play one's role well is not a matter for strategic prudence, such as that promoted by Balthazar Gracián in Spain, ${ }^{3}$ nor is the

\footnotetext{
${ }^{1}$ See A. Quondam, La Conversazione. Un modello italiano, Roma, Donzelli, 2007.

2 "Suite du commerce du monde," Euvres complètes, ed. Ch.-H. Boudhors, Paris, Les Belles Lettres, 1930 , t. III, p. 157-158. This text, posthumously published in 1700, was written in the 1680s.

${ }^{3}$ In particular in his Oráculo manual y arte de prudencia (1647), translated with great success by Amelot de la Houssaye as L'Homme de Cour (1684).
} 
"worldly science" analyzed by Girolamo Cardano about duplicity and dissimulation ${ }^{4}$ - be it of the "honest" kind that is discussed by Torquato Accetto. ${ }^{5}$ Similarly, it would be premature to relate this endeavor to a baroque sensibility fascinated by spectacle and by the ostentatious staging of social and political values. Socio-linguists, building upon the research of ethnologists, have shed light on the universal and necessary aspects of such efforts to represent the self within verbal interactions: ${ }^{6}$ this work of self-representation is at the heart of politeness, of which only the forms and requirements vary from one culture to another.

For all these reasons, it would seem appropriate to avoid the notion of baroque in accounts of practices and theories of worldly sociability (sociabilité mondaine) in seventeenthand eighteenth-century France. The no less controversial notion of classicism is, moreover, irrelevant within the context of our chronology. ${ }^{7}$ The way in which men and women of this period accompanied, and sometimes even incited, the promotion of worldly values to the point of converting them into a new aesthetic must, therefore, be apprehended on its own terms.

Maurice Magendie's pioneering study La Politesse mondaine et les théories de l'honnêteté en France, ${ }^{8}$ opens with the year 1630 - the year of publication of Nicolas Faret's L'honnête homme, a work which introduces Castiglione's Courtier to French audiences. Faret's work constitutes a milestone in the long elaboration of a model of honneteté, finalized only at the turn of the century. The work's subtitle, L'Art de plaire à la Cour, expresses-at least superficially - fidelity to the spirit of Castiglione's Courtier, a figure attached to developing the means of acquiring the favors of the Prince. But the difference in political context radically changed the stakes. France was a unified kingdom, whereas Italy was not yet a nation, its territory remaining fragmented in a multiplicity of sovereign duchies. The Court was now the court of the French monarch. The Louvre-where a crowd of courtiers sought to approach the entourage of the king in order to advance their own personal fortunes-was a far cry from the amiable Hall of Vigils at the ducal palace of Urbino. These French courtiers thus required a

\footnotetext{
${ }^{4}$ Cardano's Proxeneta, seu de Prudentia civili liber (1627) is translated into French in 1652, bearing the title La science du monde ou la Sagesse civile.

${ }^{5}$ His treatise Della dissimulazione onesta was published in 1641. See L. Van Delft et F. Lotterie, "La dissimulation honnête dans la culture classique," in L'Honnête homme et le dandy, ed. A. Montandon, Tübingen, Günter Narr, 1993, p. 35-57.

${ }^{6}$ They have done so particularly in the aftermath of Erving Goffman's La Mise en scène de la vie quotidienne, 1973 (vol. 1 La Présentation de soi, vol. 2 Les Relations en public); Les Rites d'interaction (1974). We owe to Penelope Brown and Stephen Levinson a major investigation of this question: "Universals in language use: Politeness phenomena," in Questions and Politeness. Strategies in Social Interaction, ed. E.N. Goody, Cambridge University Press, 1978, p. 56-289. A branch of linguistics has progressively specialized itself in the domain of ordinary conversation: see C. Kerbrat-Orecchionni, Les Interactions verbales, Paris, A. Colin, 1990-1994, 3 vol.

${ }^{7}$ A reappraisal of this question can be found in the issue of Euvres et critiques (XLI/1, 2016) entitled "Revaloriser le classicisme," edited by R. Zaiser.

${ }^{8}$ La Politesse mondaine et les théories de l'honnêteté en France au XVIIème siècle de 1600 à 1660, Paris, PUF, 1925.
} 
methodical guide of their own. Indeed, the supple dialogical form prized by Castiglione becomes more rigid under Faret's pen. Faret's is an organized treatise: the continuous thread of Castiglione's dialogues, in which each participant would contribute to creating the portrait of the perfect courtier, is now split into isolated rubrics. In the same decade, the 1630s, but in the city, the context changes again. A new type of civility flourished there, in the feminine ruelles - that did not yet go by the name of salons - where hostesses of high rank received their regular visitors, chosen on the grounds of personal merit alone. To please them, all erudition had to fade away, the last traces of knowledge acquired in the colleges were to disappear, to be replaced by the school of life (l'école du monde). The science of affability (science des agréments) was not to be taught, but rather acquired in the company of these exceptional women. ${ }^{9}$

The physiognomy of the French language was also progressively changing, en route towards the modern French thanks to which we can still read these classical texts today without recourse to an unwieldy apparatus of linguistic annotations. Such an evolution can only be understood in light of the forms of politesse discussed above. The "Malherbian reform," as it has sometimes been called, which began at the beginning of the seventeenth century, affected the entirety of linguistic practices and all literary genres. The oral and the written, each fashioning the other, came together in an asymptotic movement, the curves of which were formed by the conversation of honnetes gens and the reading of the best books. One was to write as one spoke, and speak as one wrote. At the end of the century, this was a matter of consensus: Marguerite Buffet, in one of the many volumes dedicated to the elegance of style, is able to assert that "the way in which we write at present is very easy; it is a natural and pleasant style [...]; one must do the same in conversation, and discuss all matters pleasantly, that is with the ease and graceful art of good speech and good writing, that is the ultimate requirement of the written word and of conversation." ${ }^{.10}$ In 1653, Madeleine de Scudéry reminds her readers: "the great secret [of conversation] is to speak always nobly about lowly things and rather simply about lofty things." "Indeed, in the 1630 s, the middle style is irresistibly promoted — a style diametrically opposed to the ostentatious figures of speech through which authors of the beginning of the century had sought to elevate French prose. ${ }^{12}$ Latin rhetoric had assigned to this mediocris style the task of pleasing (delectare). Its charms were fully consonant with the injunctions of a

\footnotetext{
${ }^{9}$ On the role women played in the fashioning of the honnête homme, see M. Fumaroli, "L'empire des femmes, ou l'esprit de joie," La Diplomatie de l'esprit, de Montaigne à La Fontaine, Paris, Hermann, 1994, p. 321-339.

${ }^{10}$ Nouvelles observations sur la langue française, où il est traité des termes anciens et inusités, et du bel usage des mots nouveaux, Paris, J. Cusson, 1688, p. 173.

${ }^{11}$ Madeleine de Scudéry "De la conversation," in De l'air galant et autres conversations (1653-1684), Ed. D. Denis, Paris, H. Champion, p. 59-75, here p. 72. See La Bruyère : "The greatest things need only be said simply [...] small things have to be said with nobility." (Les Caractères, V, 77).

${ }^{12}$ See Beugnot, "La précellence du style moyen (1625-1650)," in L'Histoire de la rhétorique dans l'Europe moderne (1450-1950), ed. M. Fumaroli, Paris, P.U.F., 1999, p. 539-599.
} 
sociability grounded in the art of pleasing (art d'agréer). Attempts to purify the French language were not limited to series of proscriptions, however. If low, technical or antiquated terms were to be abandoned, and neologisms permitted only once they had entered into common usage, it is because the goal was to form a common language, "such as it is in the ordinary commerce of honnêtes gens." "The first dictionary of the Académie française could thus do without the authorial citations that filled the pages of Richelet (1680) and Furetière's (1690) dictionaries: its examples do not simply attest to bookish usage. Rather, these examples offer-or return-the best ways of speaking and writing to the public, by proposing phraseological contexts in which given terms may be put to good use.

Vaugelas had already placed at the heart of his Remarques sur la langue française (1647) the experience of speakers originating from the "soundest part of the Court." ${ }^{\text {"I }}$ In particular, he gave pride of place to the experience of women, to whom he attributed the natural intuition of good usage. As early as the 1630s, Corneille's comedies were supposed to emulate the conversation of honnetes gens, ${ }^{15}$ endowing them in return with a certain literary prestige. On stage, their language is contrasted by Molière to the jargon of physicians or of the précieuses he ridicules. The novel, from L'Astrée onward, provides an ideal representation of this type of honest conversation and gradually opts for a style which breaks away from the flashiness of the previous generation's "phoebus speech" (parler phoebus). ${ }^{16}$ "I have endeavored to speak like the honnêtes gens," writes Georges de Scudéry in his 1641 preface to Ibrahim.

This politeness of language was a victory: in order to be successful, that is in order to literally polish language, all asperities had to be removed, and one had to renounce cutting a personal path through language. In vain voices were raised to demand linguistic freedom, ${ }^{17}$ or to recover a poetic vigor which many felt had been exhausted by the increasing blandness of modern ways of writing. ${ }^{18}$ These anti-purists were going, in all conscience, against the grain of a

\footnotetext{
${ }^{13}$ Preface of the Dictionnaire de l'Académie (1694).

${ }^{14}$ Preface to the Remarques sur la langue française, utiles à tous ceux qui veulent bien parler et bien écrire, Paris, Vve J. Camusat et P. Le Petit, 1647.

${ }^{15}$ In his Examen rétrospectif de Mélite (1660; the play had been staged in 1629), the author highlighted the novelty of his "naive style, which provided a depiction of the conversation of honnetes gens."

${ }^{16}$ Contemporaries called it the "style Nervèze," after one of the most prolific and undeniably successful novelists of the 1610s. See R. Zuber, "Grandeur et misère du style Nervèze," Les Émerveillements de la raison. Classicismes littéraires du XVIIe siècle français, Paris, Klincksieck, 1997, p. 83-95.

${ }^{17}$ Scipion Dupleix's plea for linguistic freedom is rather eloquently titled La Liberté de la langue française dans sa pureté (1651).

${ }^{18}$ Marie de Gournay was the most virulent opponent to courtly poetry, which she accuses of being excessively gentle and refined, at the expense of the type of poetic energy exemplified by Ronsard. For these reasons, she defends the use of metaphors in poetry, at a time when they are increasingly condemned in French literary usage. In 1641, she collected the entirety of her treatises, mainly composed in the 1620s, in Les Avis, ou Les présents de la Demoiselle de Gournay. See H. Lausberg, "Marie de Gournay et la crise du langage poétique," in Critique et création littéraires en France au XVIIème siècle, Paris, Éd. du C.N.R.S., 1977, p. 117-128, G. Devincenzo, "De la réflexion linguistique chez Marie de
} 
powerful movement: that of a society engaged in the process of refining civility. If language must be a common good, it is because it relies on a community of speakers; if, in the name of clarity, one must hunt down all lexical ambiguities, all syntactical equivocality, stylistic gibberish, and obscurity, it is to ensure that no misunderstandings, no hidden thoughts remain. "When we speak and when we write, we must try as much as possible," Vaugelas reminds us, "not only to be understood, but also to ensure that we cannot not be understood." 19 Such standards of clarity, drawn from classical rhetoric, ${ }^{20}$ also transmitted an ethical injunction, that of a respect for others. A sociable language was instituted, in a way that mirrored the civility of manners. It was a language within which individuals could converse freely, constrained by nothing but the necessary regard that each must have towards all. Conversation was thus the touchstone against which the qualities of the honnete homme were tested in society. One exposed oneself, in both senses of the term, since one appeared in public, thus taking the risk of making a faux pas. All aspects of savoir-vivre converged toward, and were diffracted out of, conversation: respect for the rules of propriety implied that each must find her or his place in function of each situation and each interlocutor-it was a question of aptum, of decorum. A great deal of skill was necessary to be pleasant without falling into fawning and sycophancy; wit - that is, a sense of what is appropriate to the occasion and a source of good cheer-had to prevail; pleasant mockery (la belle raillerie) contributed to it, as long as other participants were spared its bite-a bite characteristic of the persiflage of the following century. ${ }^{21}$ If there was such a thing as a rhetoric of conversation, ${ }^{22}$ at a time when the know-how associated with techniques of persuasion was no longer reserved only to the courts of law and to preaching but extended to all areas of public speech ${ }^{23}$ conversation had nonetheless dismissed eloquence, incompatible as it was with the freedom and affability of casual exchanges among honnêtes gens.

Yet all these elements were only gleaned after the fact. As is often the case, theory lagged behind practice: one would search in vain for a systematic analysis of how to conduct conversation within the first treatises on civility prior to the 1650s. It is to Madeleine de Scudéry

Gournay, Studi di letteratura francese, XXVII, 2002, p. 27-45, and D. Denis, "La douceur, une catégorie critique au XVIIe siècle," in Le Doux aux XVIe et XVIIe siècle. Écriture, esthétique, politique, spiritualité, Cahiers du GADGES, 1, 2003, p. 239-260.

${ }^{19}$ Remarques sur la langue française, op. cit., p. 591.

${ }^{20}$ Particularly from Quintilian's long exposition dedicated to perspicuitas (Institution oratoire, VIII, 2).

${ }^{21}$ See É. Bourguignat, Le Siècle du persiflage (1734-1789), Paris, PUF, 1998.

${ }^{22}$ See Chr. Strosetzki, Rhétorique de la conversation. Sa dimension littéraire et linguistique dans la société française du XVIIème siècle. Paris-Seattle-Tübingen, PFSCL, 1984. From the now overabundant bibliography on conversation, the following titles are worth mentioning: M. Fumaroli, "La conversation," in Trois Institutions littéraires, Paris, Gallimard, 1994, p. 111-210, and B. Craveri, L'Âge de la conversation, Paris, Gallimard, 2005 [La Civiltà della conversazione, Milano, Adelphi, 2001].

23 "There is nothing so important as to know how to persuade. That is, after all, what is at the heart of worldly matters. Also, there is nothing more useful than rhetoric; and to confine it to the bar or to the pulpit, it is to give it limits too narrow." (B. Lamy, La Rhétorique ou l'Art de parler, ed. C. NoilleClauzade, Paris, H. Champion, 1998, p. 103; the text is reworked several times between 1675 and 1715). 
that we owe one of its first definitions. In the "History of Sapho," of the last volume of Artamenes or the Grand Cyrus (1649-1653), the novelist depicts select company mocking the appalling conversations held at the house of Damophile. Each conversant in turn provides an example of the inappropriate topics discussed there, thereby contributing to the portrayal of this gallery of unfortunate characters. In doing so they can underline, in contrast, the qualities of their hostess. They beg Sapho, moreover, to explain to them "what conversation must be" since, as one interlocutor laments, it still has no "certain rules." Sapho gracefully complies by way of a long development. All subjects may in fact be raised in conversation, she explains carefully, since "there is nothing that cannot be said in conversation, provided that one is endowed with wit and judgment, and that one considers well where one is, to whom one is speaking and who one is oneself. However, while judgment is absolutely necessary so as never to say a single thing out of place, the conversation must nonetheless appear so free, that it would seem as if none of our thoughts are rejected and that everything that strikes one's fancy is said [...] One should never know what it is one is to say, and yet one should always know well what it is that one is saying." Above all, Sapho insists, "I wish, also, for a certain joyful spirit to reign," inspiring "in the hearts of all the company a disposition to be amused by everything and bored by nothing." 24

The recurrence of modal expressions in this passage conveys the drive toward regulation expected by Sapho's friends. These considerations have nothing to do, however, with the rigidity of precepts. The recommendations that Sapho provides at her friends' request simply elucidate the intrinsic modalities of conversation such as it was practiced in la belle société. The novelist's recommendations are clearly indebted to early theories of honnêteté, developed at length in treatises destined to readers who were not yet fully versed in these matters. ${ }^{25}$ Yet these manners are to be so well internalized that they become invisible: it behooves one to appear in society with the ease of naturel, the master concept of a fully assimilated culture of the self. To speak about everything "without transport and without affectation," as Sapho specifies, is to display the type of sprezzatura that was so dear to Castiglione, the meaning of which the term désinvolture, awkwardly proposed by his first translators, fails to capture.

In addition, the propositions put forward by Madeleine de Scudéry are expressed in the very form of the practice they purport to describe: this fictional conversation is the model for such a practice. Sapho can then modestly conclude by bestowing all the compliments awarded to conversation upon the present company itself. It is, in fact, under this pseudonym that Scudéry's contemporaries recognize her: in 1653, the date of publication of this text, Scudéry's lodgings in the Marais accommodate every Saturday her small circle of regular visitors, some members of

\footnotetext{
24 "De la conversation," op. cit., p. 72-73.

${ }^{25}$ This becomes clear, on a European scale, in the two volumes of the Bibliographie des traités de savoirvivre en Europe du Moyen Age à nos jours edited by A. Montandon (Presses universitaires de Clermont, 1995). On the French context of the seventeenth and eighteenth centuries see J. Hellegouarc'h's anthology, L'Art de la conversation, Paris, Classiques Garnier, 1997.
} 
which, like herself, had frequented the Hôtel de Rambouillet so admired throughout the century. To indirectly sing the praises of these Saturdays in such terms amounted to no less than the claim to retain their spirit. Although the bourgeois company frequenting her abode rue de Beauce had little to do with the guests chosen by the marquise d'Angennes and her daughter Julie at the Hôtel de Rambouillet, the latter two would not have refuted her analyses. In contrast to masculine erudite circles, of which there were still many at the time, Sapho's friends find themselves united by a shared "spirit of joy." In the author's conversation, the vocabulary of galanterie is recurrent: in fact, the term galant along with its lexical derivatives replaces the adjective honnête, nowhere to be found in this text.

This was a new phenomenon, which did not escape the attention of speakers of the period, and in fact baffled many of them. Witness to these hesitations which he seeks to remedy, Vaugelas exposes them in a lengthy remark which is so decisive that it is worth citing in full:

Gallant, gallantly (galant, galamment).

Gallant has several meanings, both as a noun and as an adjective. I will leave them all aside to speak only of one, which is the focus of this Remark. At the Court, they say that a man is gallant, that he says and does all things gallantly, that he dresses gallantly, and a thousand other similar things. One asks what is a gallant man, or a gallant woman of this sort, who does and says things with a gallant air, and in a gallant manner. I have seen this question debated among courtiers, indeed by the most gallant of either sex, who were hard-pressed to define it. Some maintained that it is ce je ne sçay quoi, that differs little from la bonne grâce, others argued that neither ce je ne sçay quoi nor la bonne grâce sufficed. Both, they said, are purely natural things, which must nonetheless be augmented by a certain air, that one assumes at the Court, and which can only be acquired by keeping company with the Greats and with the ladies. Others still said that these external elements were not sufficient, and that the scope of this word gallant was far greater, that it embraced several qualities at once. In short, that it was a composite notion which involved a measure of je ne sçay quoi, or of bonne grâce, of courtly air, of wit, of judgment, of civility, of courtesy and gaiety, and all without constraint, affectation or vice. With that there is enough to make an honnete homme in the fashion of the Court. This sentiment was followed as the closest to the truth, but everyone agreed that the definition remained imperfect and that there was something more in the meaning of this word that could not be expressed. Indeed, in the case, for example, of dressing gallantly, dancing gallantly, and all those other activities involving bodily gifts rather than intellectual ones, it is a notion that is easy to define, but when we move from the body to the mind, and when in conversation with the Greats and the ladies, and in the manner of dealing and living at the Court, one acquires the title of gallant, providing a definition becomes much harder, for this trait presupposes many 
excellent qualities which one would be hard put all to name, yet of which were only one to be missing, this would suffice to no longer be considered gallant. The same may be said of the lettres galantes. In these matters, France can boast of having someone to whom all others must yield. Neither Athens nor Rome, notwithstanding Cicero, have what it takes to compete with him, and I can say this boldly, since it hardly seems that a kind of writing so delicate was even known to them. And all the most exquisite tastes delight in his letters, as well as in his verse and conversation, in which one finds no less charm. I would hold the Public well-founded to bring action against him to have his works printed. ${ }^{26}$

If the meaning of the adjective is "questioned" in all the contexts in which it appears, it is because its use has gradually invaded linguistic practices. It extends to all worldly conduct, and this seemingly centrifugal force creates a deficit in meaning. But it is not given to all to know how to lead this interrogation: it is at the Court that the term is in fashion; it is there too that this quality is practiced. By way of a noticeable loop effect, Vaugelas further specifies that the "question" is debated by "the most gallant" of courtiers. To make room for it in his Remarques is not merely to propose a regulation of good usage, as Vaugelas does elsewhere: the inquiry here is of a semantic order. Good usage (le bel usage), which the continuators of Vaugelas will endeavor to clarify, is not even at stake, since the use of the adjective already pertains to good usage in the social space within which it circulates, and whose practices it describes. Ways of living and ways of talking come together in this respect: l'air galant and le bel usage have in a sense been confiscated by this elite circle. The certain je ne sais quoi, attached to la bonne grâce, yet distinct from it, does not need to be elucidated either: it operates again as a powerful agent of distinction. ${ }^{27}$ Indeed, the central notion of taste (gout) continues to function in much the same way: definitions are proposed one after another up until the very end of the century. ${ }^{28}$ Wrested from the religious sphere, to which it had been subordinated by Gracián in a chapter of The Hero (1630), taste falls well within the province of the type of gallantry that is the focus of so much attention. ${ }^{29}$ With this text, Vaugelas opens the mysteries of the air galant to an audience that is

\footnotetext{
${ }^{26}$ Remarques, p. 476-478. The italics are in the original.

${ }^{27}$ See A. Faudemay, La Distinction à l'âge classique. Emules et enjeux, Paris, Champion, 1992 and R. Scholar, Le Je ne sais quoi, Paris, PUF, 2010.

28 "It would be most appropriate to state clearly the nature of this good taste; but one senses it better than one can express it." (Méré, Euvres complètes, ed. cit., t. II, p. 128). "Everyone talks about taste, and I have as yet found no one who can properly define it" Madame Dacier also laments, in the preface to her translation of the Nuées d'Aristophane (1684), before describing it as an "interior harmony" by way of an extended musical metaphor. This analogy remains unsatisfactory to the Jesuit Dominique Bouhours, who in turn proposes his own definition of taste in La Manière de bien penser dans les ouvrages d'esprit (1687).

${ }^{29}$ The fifth conversation of the Entretiens d'Ariste et d'Eugène (1671) by Bouhours revolves entirely around the notion of je ne sais quoi, but extends well beyond the realm of socio-linguistics to embrace all the domains infused with this elusive notion. As early as 1635, the academician Gombault had dedicated
} 
not yet initiated into its secrets, but is only too pleased to learn. This is not an easy matter to carry out. The series of proposed periphrases is scrupulously recorded, and each in turn is then unpacked in this remark. No expression, however, supplants the one that comes before it. Quite to the contrary: the formula placed in italics by Vaugelas is elaborated through successive layers which allow us to grasp the very spirit of la belle conversation. As in Madeleine de Scudéry ten years later, multiple voices make themselves heard, and each plays its part.

Guided by "judgment," simultaneously a faculty of reason and a capacity for adaptation, the gallant man is thus presented as "an honnete homme in the fashion of the Court." But central as this definition may be, even in the typographic space of the page, it remains aporetic for want of exhausting the list of "excellent qualities" necessary to reach a fulness of meaning: in linguistic terms, the impossible enumeration of its inherent semes prevents one from reaching a stable definition, while constantly improving connotations (the related semes) inform us of the notion's social value. ${ }^{30}$ No doubt, the same goes for the notion of honnête homme. Indeed, these two syntagms have in common not only that they designate behaviors, but further still that they determine the forms that these behaviors must take. Their respective meanings thus have implications for the whole of worldly sociability (la culture mondaine). To understand this type of sociability, therefore, one must leave the realm of language (langue) and return words to the practice of effective speech (langage effectif). This is why the lexicologist must give way to the historian. These terms, unlike other words that only refer to their referent (a chair, for example, remains a seat), are what some linguists have proposed to call "praxemes," 31 insofar as they refer to social practices. Regarding the two expressions that concern us here, we must go further: they organize these practices, they regulate them, and that is precisely why they are so difficult to define. In the absence of a definition, models and foils can nonetheless be proposed. Some exemplary personalities can lay claim to this idealization: the Marquise de Rambouillet was a model of it for her contemporaries, Mademoiselle de Scudéry was its theoretician in another conversation on the air galant, ${ }^{32}$ the Duc de Nemours is its accomplished representative in The Princesse de Clèves, while the pedant or the uncouth provincial are its antitheses.

an entire speech to this notion - a speech presented to his colleagues, but of which no trace remains. In Bouhours, sensitive intuition is given pride of place, in a way that does justice to the element of irrational expressed in the phrase je ne sais quoi.

${ }^{30}$ See F. Rastier, Sémantique interprétative, Paris, PuF, 1987.

${ }^{31}$ The notion of praxeme, which stands in opposition to the "componential" approach of the structuralist tradition, was proposed by R. Lafont in Le Travail et la langue (1978). Claude Hagège proposes a clear definition of the stakes of this expanded semantics: "In every language, semic organization reflects the praxis of the society that culturalizes referents in a specific manner for each case and in such a way that it becomes possible to consider words as praxemes or linguistic expressions of this praxis." (L'Homme de paroles. Contribution linguistique aux sciences humaines, Paris, Gallimard, 1986, p. 288.

${ }^{32}$ It appears a few pages after the passage dedicated to conversation: "De l'air galant," op. cit., p. 43-57. "I can see clearly, Antoine Godeau writes to her in 1654, that you are going to become the oracle of gallantry for the entire universe; and that just as one speaks of Platonism, Peripateticism, not to speak of 
Vaugelas' remark concludes with literature: according to him, there is an author of his time who conforms to this nature-an author whose work has never been printed, and who thereby denies himself any such status. If his name is missing in the rubric it is, on the one hand, because its publication would have the effect of tearing the author away from the first circle of his admirers: to preserve the author's anonymity is to respect his own choice. But, on the other hand, and here Vaugelas closes the second loop of his remark: "the most gallant" of his readers will have immediately recognized Vincent Voiture, the official poet of the Hôtel de Rambouillet. Since the remaining readers are neither complicit with, nor do they share the "most exquisite tastes" of their better colleagues, it would be pointless to unveil to them the author's identity. The social signs of galanterie thus open onto its literary manifestations. Voiture is the paradigmatic example of this new way of writing, which is etched into this space of sociability. In fact, for Vaugelas, Voiture is still the only one of his kind. Vaugelas had wholeheartedly called for the publication of Voiture's works-an action which the latter's self-professed dilettantism had prevented during his lifetime. Just two years after Voiture's death in 1648, his nephew Martin de Pinchêne fulfilled this wish by publishing the long-awaited volume of his petites pièces galantes. To avoid utterly betraying his uncle's position, however, he prefaces the collection with a short text in which he portrays the poet as a perfect galant homme, even in his way of erasing all traces of an albeit very real kind of knowledge.

Voiture's singular genius is barely discussed by Pinchêne: his works testify to it. As a result, a general poetics that could reveal the characteristics of this new writing was lacking. But it was not long until it appeared. In 1655, the equally posthumous edition of the late poet JeanFrançois Sarasin's works was published. The poet's friends, Gilles Ménage and Paul Pellisson, worked to bring together his scattered productions, some of which had remained in manuscript form. The great diversity of these writings, however, should not distract us from their profound unity: that of a genuine aesthetic, as presented by Pellisson in the long Discours with which he opens the edition of Sarasin's works. ${ }^{33}$ The pleasures of amiable conversation had diffused their graces onto the poet's literary work, and for good reason since it was from this worldly sociability (sociabilité mondaine) that it had drawn its first resources-this "free, familiar and natural conversation, strewn everywhere with games, with the gaiety and civility of honnêtes gens, ${ }^{\prime 3}$ of which Sarasin was able to recover the tone. By reproducing Pinchêne's editorial gesture (a posthumous publication accompanied by a preface), Pellisson duly notes the founding place of Voiture, the poet of Rambouillet. But, to Pellisson, Sarasin is by no means an epigone: each in his own way and with his own talent had illustrated the same literary vein. By promoting

Jansenism and Molinism, that are most serious matters, we will speak of Saphonism to express the most delicate sort of gallantry."

${ }^{33}$ See L'Esthétique galante. Paul Pellisson, Discours sur les Euvres de Monsieur Sarasin et autres textes. Ed. A. Viala, E. Mortgat and Cl. Nedelec, with the collaboration of M. Jean, Toulouse, 1989.

${ }^{34}$ Ed. cit., p. 55. 
the work of his friend, Pellisson did nothing but relay the ambition he had himself exhibited in his Pompe funèbre de Voiture, published the very year of the latter's death. The stylistic virtuosity of this piece, woven with quotes and pastiches of the ancient authors that Voiture had revived by bringing lost poetic genres back into fashion, makes it unquestionably a tribute. But, in his "masterpiece of wit, gallantry, delicacy and invention," ${ }^{, 35}$ Sarasin competes with wit, playfulness, and ingenuity, and proves his own poetic mastery as well as the right to occupy the place left vacant by the recent disappearance of Voiture. That this appropriation of another's heritage makes little sense in terms of literary history hardly matters, since it is not a question of evaluating their respective value: it is Pellisson's preface that should be remembered as a manifesto. Madeleine de Scudéry probably did not participate directly in this collective edition, but it is well and truly in her entourage that it was prepared. Pellisson met her in 1653, Gilles Ménage knew her, and Sarasin himself had frequented the circle of the Saturdays in the 1650s. One grasps the coherence of their project: the reflection on forms of sociability is inseparable from a literary poetics. The air galant which they share, is precisely what needed to be defined in these two interrelated spaces. But this literature still lacked legitimacy. In particular, it lacked the authority of filiation. Once again, it is Madeleine de Scudéry who provides it in 1658 in a passage of the "History of Hesiod" inserted in Volume VIII of her Clélie (1654-1660). Asleep at the edge of the Hippocrene, the poet listens to a long prophecy pronounced by the muse Calliope, who shows him in dream-form "the progress of poetry" since its origins. The slow procession of ancient poets continues into the present and ends in apotheosis with the praise of "gallant and playful poetry," which "will be noble, natural, easy, pleasant, it will mock without malice, it will praise without great exaggeration, it will sometimes blame but without bitterness, it will be ingeniously humorous and entertaining. It will at times be tender, and at times playful [...] it will be full of pleasant inventions and ingenious simulations [that is to say, fictions], it will combine wit and love, it will have a certain worldly air that will distinguish it from other poems, and finally it will be the flower of wit of those who will excel in it." 36

The institution of this literary category was fully accomplished in the 1660s, when gallant works proliferated with titles that rallied under its banner. ${ }^{37}$ Unknown authors tried their hand at it, often without claiming to aspire to the prestige of this literary status. "All the writers in the kingdom" "38 thought themselves authorized to speak of such matters. But concerns were raised in the face of such a massive irruption of writers on Mount Parnassus where one legislated in pleasant allegorical fictions, calling to the bar witnesses and complainants of this invasion. In this context, Apollo and the Muses had a hard time sorting the winners from the losers. In 1672,

\footnotetext{
${ }^{35}$ Ibid., p. 57.

${ }^{36}$ Extract published in "De l'air galant" et autres conversations, op. cit., p. 195-244, here p. 197 and 243.

${ }^{37}$ Voir D. Denis, Le Parnasse galant. Institution d'une catégorie littéraire au XVIIe siècle, Paris, H. Champion, 2001.

${ }^{38}$ Gabriel Guéret, Le Parnasse Réformé (1668).
} 
around the same time as collections gathering small, light and playful pieces by a variety of authors, both in prose and in verse, were being assembled, Donneau de Visé launched a periodical with the eloquent title of Mercure galant. The novel was sometimes explicitly "galant." 39 Comedies and ballets were sometimes produced in the same vein. Courtly poetry relied heavily on this notion. ${ }^{40}$ One could expand the list of contemporaneous genres in which the esprit galant prevailed. Indeed, the latter knew no bounds in these years of conquest. La Fontaine is clear on this point in the preface to his Amours de Psyché et de Cupidon (1669): the taste of the century "tends toward gallantry," and this elegant jest makes the "just temperament" which is required by the "new character" of his prosimetrum. ${ }^{41}$ With The Princesse de Clèves, Madame de Lafayette inaugurated an unprecedented narrative formula which modern critics have since made the masterpiece of the classical novel, but which was then described as an "histoire galante." 42 The pleasure of reading which gallant literature self-consciously places at its very heart, is the same as the one defended by Dorante in scene 6 of La Critique de l'École des Femmes (1663), and established by him as "the rule of all rules." Racine confirms it again in the preface to Berenice (1671). What is known today as classicism flourished on this cultural breeding ground, but that was not all there was to it. On the contrary, according to the partisans of the Ancients in the famous late seventeenth-century querelle it was even necessary to detach oneself radically from this aesthetic; whereas the Moderns claimed it explicitly as their own. ${ }^{43}$ If Boileau establishes gallant aesthetics as the enemy to be fought if one does not wish to see the belles-lettres debased into trifles, it is precisely because he has measured its importance. This literature, one might say, had entered into conversation: epistles in verse respond to one another, literary portraits - so fashionable at the time - depict such worldly circles, ${ }^{44}$ light poems echo each other, authors propose their texts through public readings in the presence of select company, in the entourage of the Marquise de Sablé each maxim of La Rouchefoucauld is discussed. Previously confined to the judgment of the learned or of literary authorities, criticism itself now belonged to the man of taste: at times it also drew on dialogical modes of exposition. In the case of the quarrel provoked by the publication of The Princesse de Clèves, the Conversations of the Abbé de Charnes are written in direct response to the Lettres of Valincour. Bouhours also makes use of dialogue, whether in the Entretiens d'Ariste et d'Eugène or in his various reflections on the French language. It is through dialogue that Roger de Piles sides with color against drawing

\footnotetext{
${ }^{39}$ Cléonice ou le roman galant (1669) by Madame de Villedieu.

${ }^{40}$ See A. Génetiot, Poétique du loisir mondain, de Voiture à La Fontaine, Paris, H. Champion, 1997.

${ }^{41}$ Euvres diverses, ed. P. Clarac, Paris, Gallimard, Bibliothèque de La Pléiade, 1958, p. 123.

${ }^{42}$ Abbé de Charnes, Conversations sur la critique de la Princesse de Clèves, Paris, Cl. Barbin, 1679, p. 130.

${ }^{43}$ See L. F. Norman, The Shock of the Ancient, University of Chicago Press, 2011.

${ }^{44}$ Such as in the Divers portraits composed in 1659 in the circle of Mademoiselle de Montpensier, in exile at Saint-Fargeau at the time.
} 
in the querelle over painting that shakes the last third of the century, ${ }^{45}$ and the same goes for many late seventeenth-century treatises dedicated to ways of living, conversing and writing.

What name can we give to the type of sociability in which this modern literature flourished, and which Charles Perrault defends in his Parallèle des Anciens et des Modernes (1692-1693)? Just as Vaugelas struggled to define the air galant, and Madeleine de Scudéry had to devise a long conversation to attempt the same, so too is there here a je ne sais quoi that escapes all definition. The Roman model of casual conversation had prompted Guez de Balzac to risk the Latin calque of urbanité, "this amiable virtue of commerce." He does so in a text of 1644 that presented itself as the "Suite d'un entretien de vive voix" held in 1637 with the Marquise de Rambouillet. ${ }^{46}$ Here, as elsewhere, it is in conversation that one ponders the nature of civilité. "The bitterness of its novelty," in the words of a self-conscious Balzac himself, prevented the notion of urbanité from entering into language, and this in spite of being championed by a few authors whose efforts are vindicated by our modern usage of the term. Quite naturally, however, the word is used repeatedly by Pellisson, who seeks lexical equivalents accepted into common usage - although he ultimately fails to find a "sufficiently proper name" to express in French "this urbanité that the words civilité, galanterie and politesse explain only imperfectly." end of the century, when Perrault summarizes the achievements of modern gallantry, he uses the same nominal associations: "it comprises all the fine and delicate ways in which one speaks of all things with a free and pleasant playfulness; [it is] what Greek elegance and Roman urbanity had begun, and that the politeness of recent times has brought to a higher degree of perfection."48

Captured synchronically, all these terms are indeed quasi-synonyms, delimiting the same semantic field. But words have a history: in the space of half a century, they marked undeniable scansions. These changes took place against the backdrop of theories of honnêteté. These, in turn, had been developed through the very learning of civilité, the first precepts of which had been laid down by Erasmus. ${ }^{49}$ These precepts having been assimilated, it was in the ruelles féminines that one expected to find the urbanité of the Romans. But the casual conversations exemplified in Cicero's letters and in the dialogues of his Brutus and his Orator, have little to do with the sociability of the $1640 \mathrm{~s}$. It was the era of galanterie, and it was the novelty of this term that gave rise to the type of reflections that flourished in the social circles which practiced these forms. But what of politesse in the context of these lexical variations? Most certainly, it functioned as a generic term, but its meaning gradually_albeit significantly_changed during this period, reviving in its wake the notion of honnêteté itself. Many factors contributed to this transformation: Augustinian moralists had undermined civil virtues by uncovering the

\footnotetext{
${ }^{45}$ Dialogue sur le coloris (1671).

${ }^{46}$ Euvres diverses, ed. R. Zuber, Paris, Champion, 1995, p. 73-96.

${ }^{47}$ L'Esthétique galante, op. cit., p. 55-56.

${ }^{48}$ Parallèle des Anciens et des Modernes, Paris, Vve et Fils J.-B. Coignard, t. III, 1692, p. 286.

${ }^{49}$ De civilitate morum puerilium (1530).
} 
mechanisms of self-esteem lurking beneath the flattering mask of good manners; philosophy, after Descartes, placed individual experience at the origin of a new anthropology; the Encyclopedists of the following century devoted themselves to the rehabilitation of politesse as "a practice of natural law, all the more laudable that it is free and well founded," failing which it could be no more than a proud "desire to distinguish oneself." 50 The last third of the century durably entered into the era of suspicion. ${ }^{51}$ A more solid foundation for the talents of the worldly man was deemed necessary. "Politesse does not always inspire goodness, equity, amiability, gratitude," complains La Bruyère; "it gives the appearance of these, however, and makes the man seem on the outside as he should be within." 52

Since they are "they are easily confused," a "difference between the honnête homme and the galant homme" must, therefore, be introduced, argues the interlocutor of the Chevalier de Méré in $1668 .{ }^{53}$ If the galant homme undoubtedly possesses "certain charms, that an honnête homme does not always have, [...] those of the honnête homme are more profound." So as not to abandon the model of galanterie, which still resonated with so many, it was necessary to assert a second difference: between false galanterie, a transient effect of fashion, and "the least common" type of galanterie which "is strictly a matter of esprit and honnêteté." 54 This second form no longer depended on civil manners, it transcended them. By returning throughout his work to all aspects of worldly sociability (commerce $d u$ monde), Méré seems only to repeat lessons by then already well-known. But in doing so he renews the stakes, and the title of his treatise "De la vraie honnêteté," written around $1684,{ }^{55}$ is expressive of the transformation that honnêteté has undergone. The cards have been re-dealt.

Madeleine de Scudéry was aware of this when, in the same years, she started preparing her Conversations morales, partly taken from her novels, partly new, for publication. Her former reflections thus presented in a new light, and selected from among the extensive material offered to her by her fictions, are indicative of this change in orientation. A Dutch counterfeit rather perceptively - for this indeed was the ambition-entitled two of its volumes La Morale du monde. Far from being abandoned, questions of savoir-vivre were reexamined in this light. The first of the ten volumes (1680) opens with "La conversation," taken from the Grand Cyrus. Positioned thus, as an opening statement, it confirms the central role that is still attributed to conversation. In contrast, "De l'air galant," which immediately followed the former in the original novel, is relegated to the first volume of the Conversations nouvelles sur divers sujets,

\footnotetext{
${ }^{50}$ Article civilité, written by L. Jaucourt.

${ }^{51}$ See E. Bury, "De la vertu des payens," Littérature et politesse. L'invention de l'honnête homme, 15801750, Paris, P.U.F., 1996, p. 129-168.

${ }^{52}$ Les Caractères, "De la société et de la conversation," V, 32.

${ }^{53}$ Première conversation, ed. cit., I, p. 18-20.

${ }^{54}$ Des agréments, ed. cit., t. II, p. 43.

${ }^{55}$ This text was published only posthumously, in 1700. Méré was born in 1607: he was an exact contemporary of Mlle de Scudéry.
} 
published four years later. Moreover, it is preceded by twenty other conversations of the sort. Above all, it comes long after a previously unpublished conversation entitled "De la politesse." Having frequented the Hôtel de Rambouillet, where the Marquise had been "the worldly woman most perfectly versed in politesse," Théanor is most fit to carry out the task. The Chevalier de Méré's differentiating gesture is thus continued: "what we call the worldly air and the gallant air, are they not practically the same thing as politesse?" asks one of Théanor's interlocutors. The latter's response is unambiguous: "These airs usually arrive in its wake; politesse is something more solid, more essential, and more necessary [...] In a word, true politesse is literally a savoirvivre." But the apparent equivalence with the modern expression savoir-vivre is misleading. This skill goes well beyond the mastery of social signs: it involves an ethics of one's relationship to others. To this extent, "one must know morality to know politesse well." This savoir-vivre (know-how) is in fact a devoir-être (must-be).

The collection of terms assembled by Pellisson is not to be dismantled. At the time when he is writing his Discours on the works of Sarasin, they formed an operational constellation. But, as we have seen, a closer look reveals that these terms can be reorganized over the brief span of three decades. The years in which the category of the honnete homme was instituted provided the means for the kind of refinement of manners to which galanterie refers. Indeed, the middle of the century acts as a "turning point." These are the "Foucquet years." They are the years of festivities at Vaux-le-Vicomte, the glamor of which was celebrated by La Fontaine. They are above all the festive years of the monarch's young Court. Indeed, Foucquet, the Superintendent of Louis XIV, pays the high price of this unequal rivalry when he is brutally disgraced in 1661 . When the Court moved to Versailles in 1682 and Madame de Maintenon began to infuse it with an air of piety, politesse could be said to have been "moralized." Is all of that to say that the moment galant was over? Absolutely not: in a new economy of relations between men and women, brilliant conversation durably remained a matter of galanterie, and the latter continued to be identified with modernity. ${ }^{56}$ The benefits were no less great on the aesthetic level. The conversion of civil manners into artistic value could not be founded on the basis of theories of honnêteté: only a culture of signs, in all its manifestations, could make such a conversion possible. The work of Marivaux - to name but one literary example — is largely indebted to this culture; Watteau's Fêtes galantes portrays its graceful forms $;^{57}$ Rameau devotes an opera to it; ${ }^{58}$ Verlaine pays homage to these bygone times in an evocatively titled collection. ${ }^{59}$

\footnotetext{
${ }^{56}$ Hume recognizes this in 1742 in his essay On the Rise and Progress of the Arts and Sciences: "If the superiority in politeness should be allowed to modern times, the modern notions of gallantry, the natural produce of courts and monarchy, will probably be assigned as the causes of this refinement." (in Standard of Taste and Other Essays, New-York, Bobbs-Merrill, 1965, p. 89. Cited by L. F. Norman, The Shock of the Ancient, op. cit., p. 120).

${ }^{57}$ This title refers to a series of paintings created around 1715, which can be said to culminate in the creation of Le Pèlerinage à l'île de Cythère, presented at the Académie de peinture in 1717. Watteau thus inaugurated a pictorial genre that was especially prized by collectors throughout Europe. Frederick II,
} 
Galanterie - that fine flower of a long process of civilization-is a savoir-vivre only if one is capable of taking the expression seriously, as Madeleine de Scudéry did in her time. Conversation was the crucible of this savoir-vivre: to converse was not simply a matter of exchanging remarks, it was a demanding way of living together. Of course, it remained an ideal and not a faithful representation of what social relations were. There was certainly no shortage of political intrigues: literary cabals were set up, dangerous liaisons were formed, and conquests were paraded. Rousseau will have no difficulty in unmasking the insincerity of seductive Parisian conversations in La Nouvelle Héloïse, attributing to Saint-Preux the corrosive analyses of his letters to Julie, written during his stay in the capital. But to see in Molière's Alceste of the Misanthrope a model of the honnête homme, as Rousseau does in Émile ou de l'éducation, is a reading to which the previous century would certainly not have subscribed - in the name of an enlightened sociability.

emperor of Prussia, requested that his castles of Charlottensburg and Sans-Soucis be decorated with works by Watteau and other painters that had gained renown after him for representing this genre of scenes.

${ }^{58}$ The opera-ballet entitled Indes galantes was created in August 1735.

59 The collection of Fêtes galantes is published in 1869. For a more comprehensive study of these cultural manifestations, see A.Viala, La France galante, Paris, PUF, 2008. 